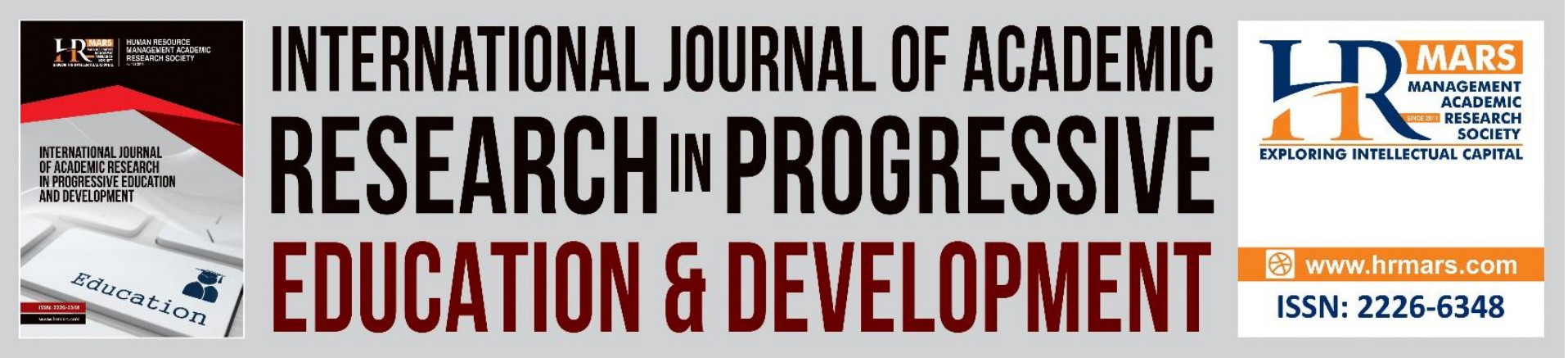

\title{
Developing a Mathematics Module in Support of Secondary School Reflective Learning
}

\section{Asmahwati Binti Rosli, Wun Thiam Yew, Ahmad Zamri Khairani}

To Link this Article: http://dx.doi.org/10.6007/IJARPED/v10-i1/8175

DOI:10.6007/IJARPED/v10-i1/8175

Received: 08 January 2021, Revised: 09 February 2021, Accepted: 27 February 2021

Published Online: 15 March 2021

In-Text Citation: (Rosli et al., 2021)

To Cite this Article: Rosli, A. B., Yew, W. T., \& Khairani, A. Z. (2021). Developing a Mathematics Module in Support of Secondary School Reflective Learning. International Journal of Academic Research in Progressive Education and Development, 10(1), 457-469.

Copyright: (C) 2021 The Author(s)

Published by Human Resource Management Academic Research Society (www.hrmars.com)

This article is published under the Creative Commons Attribution (CC BY 4.0) license. Anyone may reproduce, distribute, translate and create derivative works of this article (for both commercial and non-commercial purposes), subject to full attribution to the original publication and authors. The full terms of this license may be seen

at: http://creativecommons.org/licences/by/4.0/legalcode

Vol. 10(1) 2021, Pg. 457 - 469

Full Terms \& Conditions of access and use can be found at http://hrmars.com/index.php/pages/detail/publication-ethics 


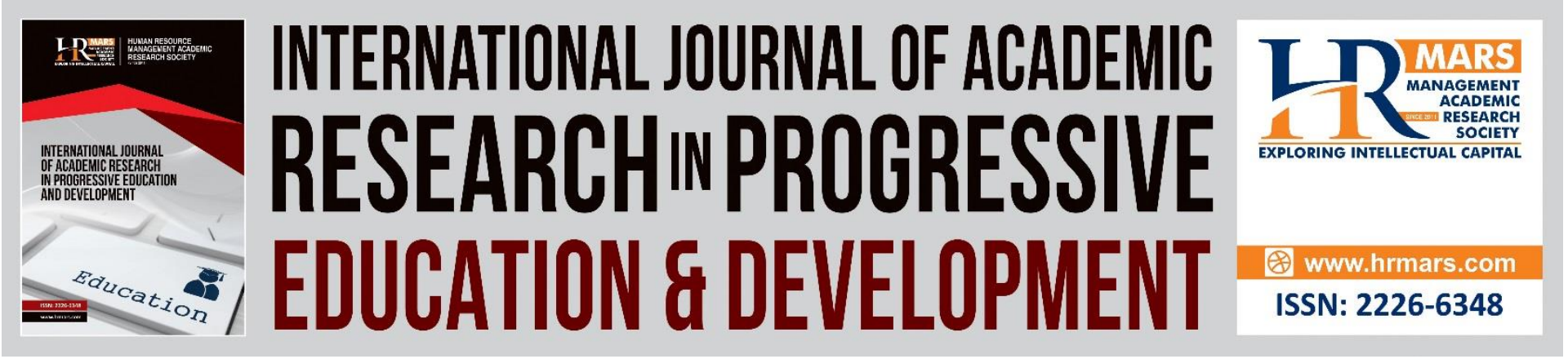

\title{
Developing a Mathematics Module in Support of Secondary School Reflective Learning
}

\author{
Asmahwati Binti Rosli ${ }^{1}$, Wun Thiam Yew², Ahmad Zamri \\ Khairani ${ }^{3}$ \\ ${ }^{1}$ Kuala Kangsar Education District Office, Perak, Malaysia, ${ }^{2,3}$ School of Educational Studies, \\ Universiti Sains Malaysia, Penang, Malaysia
}

\begin{abstract}
Reflective learning is a teaching method where active student learning is a core component of instructional design. In mathematical instructions, reflection and knowledge-construction take place in the language of mathematics. The development of mathematics module in the current study employs three computer-mediated communication (CMC) tools: Google Classroom, discussion forum and text messaging. This study seeks to determine the communication and learning forms which support reflective learning in the usage of CMC tools within the mathematics module. 30 Form 2 students with different mathematical abilities were selected as participants. Data collection include students' online communication on Google Classroom (GC), forum discussion, and text messaging. A survey of students' perception of communication using $\mathrm{CMC}$ tools and learning were also distributed. Google Classroom and text messaging were reported to have the highest frequency of communication among learners. The combined usage of the three CMC tools was found to be effective as it caters to learners' preferred learning styles, encouraging collaboration and experiential learning. This study offers insights into group interaction in a reflective learning environment and its influence on the scaffolding of mathematics knowledge.
\end{abstract}

Keywords: Reflective Mobile Learning, Computer-Mediated Communication Tools, Mobile Learning, Google Classroom

\section{Introduction}

Reflective learning approaches emphasize active student engagement in teaching and learning (Dewey 1933; MDPI, 2020; Schön, 1983) where the acquisition of knowledge, skills and attitudes are results of group interactions (Minot, 2015; Potkonjak, 2016; Smith et al., 2016). When CMC tools are employed in these interactions, reflective mobile learning is said to occur. This phenomenon allows group interactions outside the formal classroom environment, encouraging learning in the situated environment (Müller \& Faltin, 2011; Pitts, 2015).

The advancement of information technology (IT) initiated the development of various computer-mediated communication (CMC) and social networking tools (May, 2008; Ou et al., 2013), allowing content-sharing to take place efficiently, and in real-time. However, the effect 
of computer-mediated communication (CMC) tools for reflective learning remains underexplored. Reflective learning is especially useful in scaffolding support and generating ideas through the use of different CMC tools such as discussion forums (DeWitt et al., 2013: Haines, 2015; Sun et al., 2018), Google Classroom (Becker et al., 2018; Kondos, 2018) and text messaging (Li \& Lewis, 2018; Sun et al., 2018).

CMC tools have been implemented in teaching mathematics (Hadjinicolaou, 2018) where the lessons combined two tools: text messaging and Google Classroom (Milman, 2018), as well as, text messaging and a discussion forum (Winoto, 2018). These lessons were proven to be effective in the teaching and learning of mathematics. The current study will investigate the combination of two tools in developing a Mathematics module.

\section{Literature Review}

Teaching materials are subject matter content compiled completely and systematically based on the pedagogical principles employed by teachers and students alike. These materials can be categorized into print and non-print (Depdiknas, 2008). Print teaching materials consist of textbooks, modules, worksheet, practical guide, and the likes, while non-printable materials can be online games, e- modules, interactive videos, and virtual labs. The selection of the teaching materials must be determined appropriately according to robustness and student's learning style (Wenno, 2010).

Figure 1.1 presents the three main questions in conducting reflective learning according to the reflective model introduced by Borton (1970). These questions prompt an explanation of a given situation, leading one to analyse the situation and construct knowledge based on what one has learned through experience. Practitioners then improve it based on the consequences of their reactions to the experience.

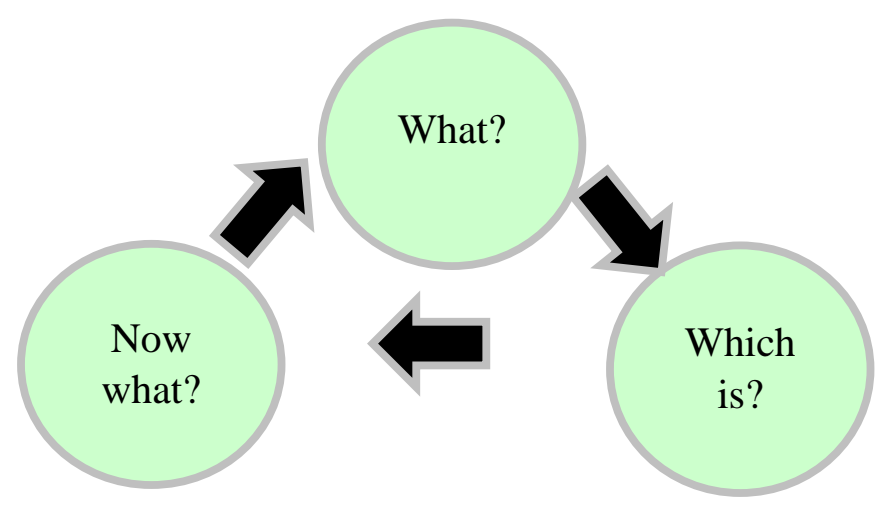

Figure 1.1. Reflective model (Borton, 1970).

Another reflective model introduced by Kolb (1984) highlighted the concept of learning based on experience and knowledge transformation (see Figure 1.2) that occurs after the event, and involves the practitioner reflecting on these experiences. After gaining a general understanding of the concepts encountered, the general understanding was then tested in a new way. In this way, knowledge is formed from the conditions that are constantly being applied and reapplied, building on the experience of the practitioners and knowledge. These $\mathrm{CMC}$ tools enable cognitive change in learners as ideas are challenged and debated upon to create new knowledge (Chan, 2012). 
Concrete

Experience (CE)

Experimentation

(AE)

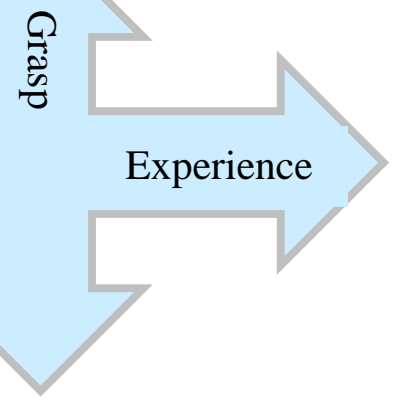

Abstract

Conceptualisation

(AC)
Reflective

Observation

(RO)

Figure 1.2. Kolb model (Kolb, 1984).

The teaching training module is a systematic and reflective process in developing teaching and learning principles for lesson plans, teaching materials, information resources and assessments (Smith \& Ragan, 2005). Reiser and Dempsey (2007) agreed on a similar notion in the advancement of education and training based on creativity while Kemp, Morrison, and Ross (1998) argued that teaching training modules are teaching processes based on practice.

Studies by Ros Eliana Ahmad Zuki (2014), Mas Norbany Abu Samad (2016) and Tee (2013) demonstrated the positive impact of these modules where there is a significant difference in terms of student achievement. In ensuring that module effectiveness can be achieved, certain aspects such as target groups, module contents, facilitator capabilities, relevant time and objectives are emphasised upon. Modules and appropriate learning processes generate motivation and learning stimulation that provides good learner psychological effects (Novitasari et al., 2016).

Learning activities are a major component of good modules that accommodate active processes. Learning activities should be contextualised within a student environment (Widodo et al., 2017) as an additional supplement to the active process of discovery. Thus, the knowledge gained in learning is more accurate and memorable as they are directly practised (Ali et al., 2010).

\section{Research Questions}

This research aims to determine the forms of communication and learning among learners in the development of a reflective learning mathematics module. This study seeks to answer the following research questions:

1. How do learners communicate in the development of a reflective learning mathematics module?

2. How do learners learn with the Mathematics module as reflective learning support? 
DEVELOPMENT

Vol. 10, No. 1, 2021, E-ISSN: 2226-6348 @ 2021 HRMARS

\section{Methodology \\ Participants}

The reflective learning mathematics module was developed based on a survey of communication tools accessed by learners. An urban secondary school was selected to implement the mathematics module on the topic of speed and acceleration. The module was implemented among thirty 14-year-old students where participants' perceptions on learning and communication while using the module were captured through observations, online communications and a survey of the module. The participants consisted of an equal number of high, medium and low achievers in mathematics where most of them owned a mobile phone $(89.6 \%)$ and have access to computers (84.5\%). Laptops and mobile phones were also made available during the implementation since mobile phones were required for text messaging after school hours. Participants who needed a mobile phone could borrow one.

\section{Data Collection}

A pre-test on the knowledge items in the module was conducted before the module implementation. During the implementation, data was collected from online communication on Google Classroom (GC) and text messages. At the end of the module, a post-test was conducted using a survey to determine learners' perception of their understanding and required learning support. Triangulation of data was done through the analysis of online communications.

\section{Development of the Module}

The development of the reflective learning mathematics module considered the CMC tools which learners have accessed. This module was developed on Google Classroom where resource links to content, videos, animations, and tasks were offered using CMC tools. The topic of Speed and Acceleration was selected as there are many misconceptions in this topic (Tabachnick et al., 2018). Secondary school students are often confused when it comes to comprehending physico-mathematical relations and their deep interpretation (Mwangala \& Shumba, 2016).

\section{CMC Tools in the Mathematics Module for Reflective Learning}

The reflective learning mathematics module consisted of online lessons and face-toface meetings (see Table 1). The activities in the module include problem task, group work assigned on Wiki, related questions on discussion forums and quizzes on text messages. The teacher provided feedback and support for all the tasks. Table 2 provides a summary of all the $\mathrm{CMC}$ tools used in the mathematics module for reflective learning. 
DEVELOPMENT

Vol. 10, No. 1, 2021, E-ISSN: 2226-6348 @ 2021 HRMARS

Table 1

Lessons in the mathematics module for reflective learning

\begin{tabular}{cc}
\hline Lessons & Title \\
\hline Initial* $^{*}$ & Orientation to module \\
1 & Speed as a rate \\
2 & Uniform and non-uniform speed \\
3 & Average speed \\
4 & Solving problems involving speed \\
5 & Acceleration and deceleration \\
6 & Unit conversion \\
7 & Solving problems involving acceleration \\
Final* & Summary \\
\hline
\end{tabular}

*Face-to-face meetings

Table 2

Tools and activities in the Mathematics module

\begin{tabular}{|l|l|}
\hline \multicolumn{2}{|c|}{ The Mathematics module } \\
\hline \multicolumn{1}{|c|}{ CMC tool } & \multicolumn{1}{c|}{ Activity } \\
\hline Google Classroom (GC) & $\begin{array}{l}\text { Group Activity: Groups of 3-4 students } \\
\text { The task is to analyse the speed and } \\
\text { acceleration topic in a given example and } \\
\text { post their findings on GC. Each group has a } \\
\text { specified GC and can add additional } \\
\text { comments. }\end{array}$ \\
\hline Text Messaging & Individual Activity: Telegram Quiz \\
\hline
\end{tabular}

\section{Data Analysis}

The data collected were analysed to identify how students communicate and learn in a reflective learning environment. The results of the pre-test were compared to the post-test at the end of the module to determine if there were differences in the scores, indicating learning efficacy. As for the survey conducted after the implementation of the module, descriptive analysis was used to analyse the responses.

\section{Results}

The discussion is focused on two areas of the reflective learning mathematics module, communications and learning. The findings provided insights into the communications of the mathematics module to support reflective learning and the contribution to learning mathematics.

\section{Communication in the Reflective Learning Module}

In order to investigate learners' communication in the mathematics module, two domains were analysed: the frequency of $\mathrm{CMC}$ tools usage and different types of group activities. 
DEVELOPMENT

Vol. 10, No. 1, 2021, E-ISSN: 2226-6348 @ 2021 HRMARS

\section{CMC Tools}

The frequency of using the $\mathrm{CMC}$ tools to complete the assigned tasks varied among participants (see Figure 2). Participants were most active on the Telegram Quiz (85 log-ins) due to the accessibility offered by mobile devices. In addition, personalized feedback was also provided during the Telegram Quiz.

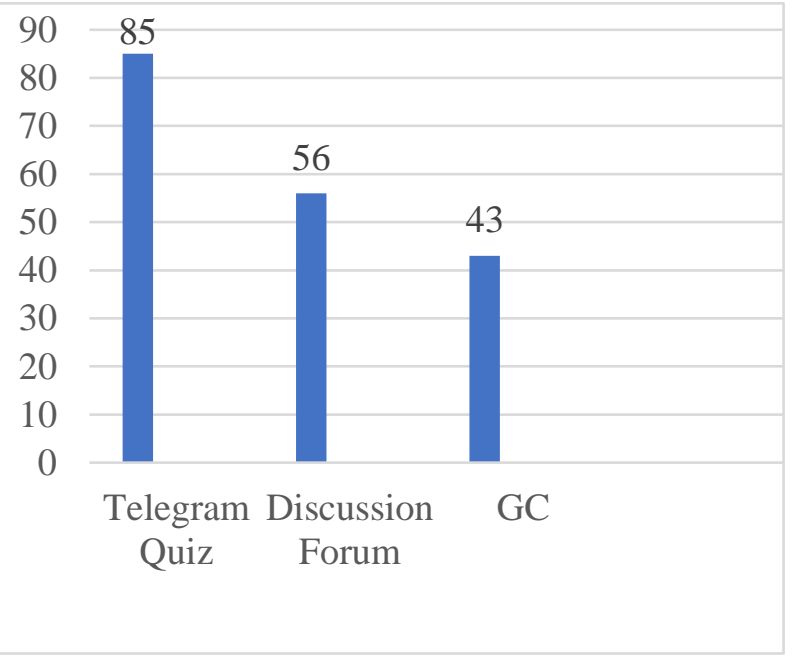

Figure 2. Frequency of log-ins for CMC tools $(n=20)$.

There were a large number of postings on the discussion forum ( 56 responses) but the analysis showed that only an average of 24 participants had responded. Most responses were posted by two or more learners, indicating the participants' preference for group work since the participants are required to collaborate with their peers before posting in the discussion forum.

GC was the least accessed ( 43 log-ins) by only 21 participants as compared to the other tools. However, participants were engaged with the task on GC from the first week where they edited their group GC, as well as, created, distributed and animated video meeting and grading assignments. There was only one group in which members failed to cooperate and no activity was detected.

In sum, the mobile phone is a personal device which offers easy accessibility and, hence, is the most frequently used. There were fewer posts in the discussion forums and Wiki where the learners were working in groups despite, but both tools are useful for group responses. On the other hand, the GC enabled artefacts such as graphics and text to be used in communication. 
DEVELOPMENT

Vol. 10, No. 1, 2021, E-ISSN: 2226-6348 @ 2021 HRMARS

\section{Working in Groups}

Participants preferred working in groups as can be seen in Figure 3, where group task on GC was attempted by most participants. In addition, contributions to the discussion forum were posted by participants belonging to groups of two or three.

Figure 3. Participants' perception of group work $(n=30)$.

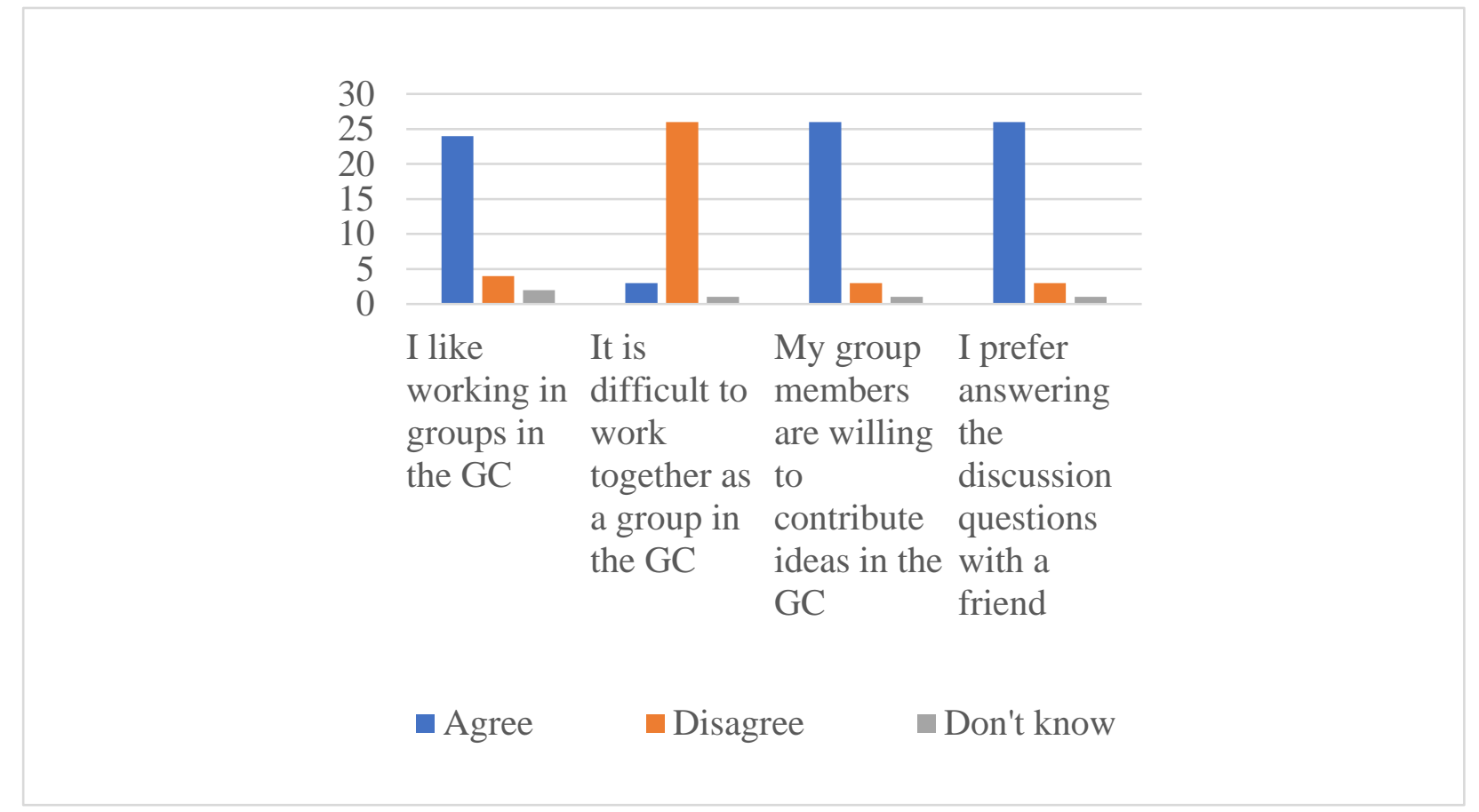

Results from the survey revealed that participants preferred to work in a group for both the online tasks (80\%) and discussion forum (87\%) and did not perceive group work as difficult (67\%) (see Figure 3). Most perceived that their group members are willing to contribute ideas (87\%). Group discussions were conducted face-to-face discussions and extended to text messages on Telegram and GC chat.

\section{Learning in the Reflective Learning Module}

Learning with the reflective learning mathematics module was investigated by understanding mathematics and learning support.

A pre-test and post-test on the similar concepts reported an increase in the mean scores of the participants. The paired sample t-test for statistical analysis was computed for 30 participants who completed both pre-test and post-test. The difference in the mean scores showed an increase indicating that the module was effective for learning mathematical concepts (see Table 3).

Table 3. Mean of pre-test and post-test scores of participants, $n=30$

\begin{tabular}{ccc}
\hline \multicolumn{2}{c}{ Mean scores } & Increase in \\
Pre-test & Post-test & $\begin{array}{c}\text { mean scores } \\
\text { men }\end{array}$ \\
\hline 58.97 & 84.07 & 25.09 \\
\hline
\end{tabular}




\section{Discussion}

The mathematics module enhanced understanding of mathematical concepts related to speed and acceleration. Learners made references to materials, both online and print, enabling learners to formally model their answers during informal discussions. The findings of this study support the implementation of reflective learning in secondary school for mathematics. Communication processes on Wiki and discussion forums are public and present a permanent answer to the problem. At the same time, informal communications in constructing the solution contribute to the thought process. These interactions and discussions are beneficial for learning and constructing mathematics knowledge as proven by the results of the pre-test and post-test. These findings are also relevant as participants are from different level of mathematical abilities. Future studies can determine the effectiveness of reflective learning in mathematics module with a larger sample since the current study only involved 30 participants.

Previous studies have reported a combined use of several tools for learning where the combination of two tools was more effective than one. Not all learners will utilise CMC tools during implementation. By providing several tools as options, learners can respond by using the most suitable tool for learning. GC lends itself to collaborative problem solving; discussion forums are best for debates and arguments while text messaging are effective for factual and conceptual knowledge. This study also confirms that text-messaging can be used for informal discussions in knowledge-building besides being a stimulus for formal learning, especially in quizzes.

The preference for different $\mathrm{CMC}$ tools is related to learners' learning styles and convenience. Both components are potential areas for further research. In addition, future studies can also investigate if there are any significant differences between the usages of one, two or three CMC tools.

\section{Conclusion}

Findings confirmed that the development of mathematical module in support of reflective learning can be used to address learning needs in the field: (1) appropriate tool as teaching material in the development of a reflective learning mathematics module, (2) Mathematics teachers are expected to use this module during the process. The module can be used for mathematical learning outside school hours and address the issue of time constraint for classroom discussion.

The findings of the study reinforce the fact that important for learners to plan, share ideas, develop their understanding and promote critical thinking in a collaborative environment (Chikiwa \& Schäfer, 2018; Ellerton, 2003). Communication contributes greatly to the learning of mathematics.

In conclusion, social learning in the use of mathematics module for reflective learning can also be extended to science subject. The social interaction aspect for knowledge-building through formal and informal learning can also be extended to other subjects as well. Contextual components, including participants' answers, are artefacts to "mediate" learning. Hence, in the mathematics module, if non-participation did not mean the learner was inactive. Learning could take place formally and informally when other learners' answers and interactions mediated learning. 


\section{References}

Ali, R., Ghazi, S.R., \& Khan, M.S. (2010). Effectiveness of Modular Teaching in Biology at Secondary Level. Asian Social Science, 6 (9), 49-54.

Becker, V., Gambaro, D., Saraiva Ramos, T., \& Moura Toscano, R. (2018). Audiovisual Design: Introducing 'Media Affordances' as a Relevant Concept for the Development of a New Communication Model. In Communications in Computer and Information Science (Vol. 813, pp. 17-31). Springer Verlag. https://doi.org/10.1007/978-3-319-90170-1_2

Borton, T. (1970). Reach, touch, and teach: student concerns and process education. New York, NY: McGraw-Hill.

Chan, C. K. Y. (2012). Exploring an experiential learning project through Kolb's Learning Theory using a qualitative research method. European Journal of Engineering Education, 37(4), 405-415. doi: 10.1080/03043797.2012.706596

Chikiwa, C., \& Schäfer, M. (2018). Promoting critical thinking in multilingual mathematics classes through questioning. Eurasia Journal of Mathematics, Science and Technology Education, 14(8). https://doi.org/10.29333/ejmste/91832

Depdiknas. (2008). Panduan Pengembangan Bahan (1): 112-121. (2016). Pengembangan Modul Pembelajaran IPA Terpadu Berbasis Inkuiri Terbimbing Tema Matahari Sebagai Sumber Energi Alter natif Di Kelas VII SMP/ MTs. .Jurnal Inkuiri 5 Ajar. Jakarta: Depdiknas

Dewey, J. (1933). How we think: A restatement of the relation of reflective thinking to the educative process. Boston: D.C Health \& Co doi: 10.1037/10903-000.

DeWitt, D., Siraj, S., \& Alias, N. (2013). Collaborative mlearning: A module for learning secondary school science. Educational Technology and Society, 17(1), 89-101.

Ellerton, N. F. (2003). Language factors and their relevance in problem posing and problem solving in primary mathematics and science classrooms. Proceeding of Best Practices and Innovations in The Teaching and Learning of Science and Mathematics at the Primary School Level (pp. 15-33). Kuala Lumpur, Malaysia: Ministry of Education Malaysia.

Hadjinicolaou, M. (2018). Virtual Class - An Appropriate Environment for Distance Learning Mathematics at an Open University. European Journal of Open, Distance and ELearning, 17(1), 147-153. https://doi.org/10.2478/eurodl-2014-0010

Haines, K. J. (2015). Learning to identify and actualize affordances in a new tool. Language, Learning and Technology, 19(1), 165-180.

Kemp, J. E., Morrison, G. R., \& Ross, S. M. (1998). Designing effective instruction. New Jersey: Prentice-Hall Inc.

Kolb, D. A. (1984). Experiential learning: experience as the source of learning and development. Englewood Cliffs, New Jersey: Prentice-Hall.

Kondos, S. (2018). The Effect of the Use of Technology on the Nature of Teacher's Profession. SSRN Electronic Journal. https://doi.org/10.2139/ssrn.3150910

Li, J., Zhang, X., \& Hu, Z. (2018). The design and application of flip classroom teaching based on computer technology. International Journal of Emerging Technologies in Learning. doi: 10.3991/ijet.v13i10.9453

May, M., George, S., \& Prévôt, P. (2008). A closer look at tracking human and computer interactions in web-based communications. Interactive Technology and Smart Education, 5(3), 170-188. https://doi.org/10.1108/17415650810908258

Milman, N. B. (2018). Incorporating Asynchronous Online Discussion in Blended and Online Education: Tools, Benefits, Challenges and, Best Practices. In R. J. Harnish, K. R. 
Bridges, D. N. Sattler, M. L. Signorella, \& M. Munson (Eds.), The use of technology in teaching and learning (pp. 109-120). The Society for the Teaching of Psychology. Retrieved from http://teachpsych.org/ebooks/

Minott, M. A. (2015, July). Encouraging secondary students' deep reflection-on-learning: A case for a reflective approach to evaluating students' learning. Reflective Practice, 3943, 1-10. doi: 10.1080/14623943.2015.1064375

Müller, N., \& Faltin, N. (2011). IT-support for self-regulated learning and reflection on the learning process. In ACM International Conference Proceeding Series. https://doi.org/10.1145/2024288.2024299

Müller, N., \& Faltin, N. (2011). IT-support for self-regulated learning and reflection on the learning process. In ACM International Conference Proceeding Series. https://doi.org/10.1145/2024288.2024299

Mwangala, K. P., \& Shumba, O. (2016). Physico-mathematical Conceptual Difficulties among First Year Students Learning Introductory University Physics. American Journal of Education Researsh, 4(17), 1238-1244.

Novitasari, E., Mohammad, M., \& Nonoh, S. A. (2016). Pengembangan Modul Pembelajaran IPA Terpadu Berbasis Inkuiri Terbimbing Tema Matahari Sebagai Sumber Energi Alter natif Di Kelas VII.

Ou, C. X., Sia, C. L., \& Hui, C. K. (2013). Computer-mediated communication and social networking tools at work. Information Technology and People, 26(2), 172-190. https://doi.org/10.1108/ITP-04-2013-0067

Pitts, K., Pudney, K., Zachos, K., Maiden, N., Krogstie, B., Jones, S., ... Turner, I. (2015). Using mobile devices and apps to support reflective learning about older people with dementia. Behaviour and Information Technology, 34(6), 613-631. https://doi.org/10.1080/0144929X.2015.1015165

Pitts, K., Pudney, K., Zachos, K., Maiden, N., Krogstie, B., Jones, S., ... Turner, I. (2015). Using mobile devices and apps to support reflective learning about older people with dementia. Behaviour and Information Technology, 34(6), 613-631. https://doi.org/10.1080/0144929X.2015.1015165

Potkonjak, V., Jovanovic, K., Holland, O., \& Uhomoibhi, J. (2016). Distance learning and skill acquisition in engineering sciences e present state and prospects. Multicultural Education and Technology Journal, 7(1), 64-88.

Reflective Learning in Higher Education. (2020). Reflective learning in higher education. MDPI. https://doi.org/10.3390/books978-3-03936-592-0

Reiser, R. A., \& Dempsey, J. V. (2007). Trends and issues in instructional design and technology. New Jersey: Pearson Education Inc.

Zuki, R. E. A. (2014). Model dan modul pengajaran integrasi holistik guru pelatih pendidikan teknik dan vokasional. Thesis Doktor Falsafah. Universiti Teknologi Malaysia

Schön, D. A. (1983). The reflective practitioner. Pediatrics, 116(6), 1546-52. doi: 10.1542/peds.2005-0209.

Siraj, S., \& Alias, N. (2005). An evaluation of Mlearning. The International Journal of Learning, 12(4), 187-198. Retrieved 20 March 2013 from http://ijl.cgpublisher.com/product/pub.30/prod.674

Smith, L. P., \& Ragan, J. T. (2005). Instructional design (Third Edition). United States of America: John Wiley \& Sons, Inc.

Sun, Z., Lin, C. H., Wu, M., Zhou, J., \& Luo, L. (2018). A tale of two communication tools: Discussion-forum and mobile instant-messaging apps in collaborative 
learning. British Journal of Educational Technology, 49(2), 248-261. https://doi.org/10.1111/bjet.12571

Tabachnick, E., Colesworthy, P., \& Wittmann, M. C. (2018). Middle school physics teachers' content knowledge of acceleration (pp. 384-387). American Association of Physics Teachers (AAPT). https://doi.org/10.1119/perc.2017.pr.091

Tee, T. Z. (2013). Pengintegrasian kemahiran berfikir dan peta minda buzan bagi penguasaan kemahiran berfikir aras tinggi. (Tesis ljazah Doktor Falsafah). Universiti Tun Hussein Onn Malaysia.

Wenno, I. H. (2010). Pengembangan Model Modul IPA Berbasis Problem Solving Method Berdasarkan Karakteristik Siswa Dalam Pembelajaran di SMP/ MTs. Educational Horizon, 2, 176-188.

Widodo, A., Maria, R. A., \& Fitriani, A. (2017). Constructivist learning environment during virtual and real laboratory activities. Biosaintifika 9 (1): 11-18.

Winoto, P., Chen, J., Guo, H., \& Tang, T. Y. (2018). A mathematical and cognitive training application for children with autism: A system prototype. In communications in computer and information science (Vol. 851, pp. 114-119). Springer Verlag. https://doi.org/10.1007/978-3-319-92279-9_16 
Dr. THAVAMARAN KANESAN

Chief Editor,

Company: Proofreading by A UK PhD (ProofreadingByPhD.com) Registration: NSO163592-K

Email: drThava@proofreadingbyphd.com

Mobile: +60176712515

\section{PROFESSIONAL PROOFREADING CERTIFICATE}

This document certifies that the material detailed below underwent a thorough proofreading process, and was subsequently improved in terms of English language, grammar, punctuation, spelling, overall styling and quality-of-expression.

Title:

Developing a Mathematics Module in Support of Secondary School Reflective Learning

\section{Author:}

Asmahwati Rosli ${ }^{1}$, Wun Thiam Yew ${ }^{2}$, Ahmad Zamri Khairani ${ }^{3}$

Affiliation:

1,2,3 School of Education Studies, University Sains Malaysia, 11800, Penang, Malaysia

Date Issued: $2^{\text {nd }}$ December 2020

Yours truly,

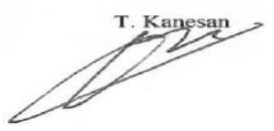

$$
\begin{gathered}
\text { Dr. Thavamaran Kanesan, BEng (Hons), PhD (UK), MIEEE } \\
\text { Chief Editor } \\
\text { PROOFREADING BY A UK PhD (NS0163592-K) } \\
\text { https://www.facebook.com/proofreadingbyPhD/ } \\
\text { Proofreadingbyphd@gmail.com } \\
0176712515
\end{gathered}
$$

\section{sfep}

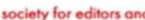

\footnotetext{
- 12,600 Documents Proofread/Edited/Structured/Paraphrased

- 6,100+ Articles Accepted in SSCI/SCI/HSCI/Scopus/ERA

- 4,000+ Theses Passed Viva

- 500+ Grant Documents Approved

$-500+C V$ and Research Statements Completed 